\title{
Wild Flower Protection
}

\author{
Professor C. W. LOWE \\ Formerly of the Dept. of Botany, University of Manitoba
}

The question of Wild Flower Protection is part of a much greater problem - the conservation of all our natural resources. Some of our resources are exhaustable; these are oil, coal, gas and minerals. Others, such as our plant and animal life are not so liable to disappear from the earth if they are wisely controlled and protected. The present great increase in the world's population and the rapid expansion of towns and cities are reducing considierably the area of the earth's surface which is capable of supporting our indigenous plant and animal life. There are many people who do not realize that every green leaf takes its quota of the poisonous carbon dioxide from the atmosphere and gives back the life-giving oxygen in its place. Plant life also is either the cirect or indirect source of food for all animal life including man. With growing cities and diminishing fields and forests, it behoves us to protect all our forests, keep our fields green, and make the wisest possible use of all natural resources if future generations are to have the joy of outdoor life that we now have.

It has long been recognized that if our game birủs, mammals, and fish are to continue to live and multiply so that future generations can enjoy them as we do now, then these creatures must be protected for months or even years at a time. If these forms of life, which have the power within themselves to flee from man, need protection, how much more is the need for our trees and small flowering plants to be protected? Just as some of our birds have become extinct in recent years and others threatened with extinction, so are some of our prettiest and most attractive flowers fast disappearing from our midst.

Since the end of World War One, the red prairie lily, the yellow lady's slipper, the orchid, the puccoon and other flowers have almost entirely disappeared from around Sturgeon Creek and St. Charles. The pink, showy lady's-slipper, once plentiful between the Red River and Gonor, is now quite rare. Birds Hill, twentyfive years ago, had a varied and interesting flora, but now only weeds flourish there. The beautiful fringed gentian and other lovely blue gentians are now diffiult to find in many of the more settled parts of Manitoba. In many country areas, the farmers have plowed up every bit of land possible, until, in many townships, it is impossible to find even a few square yards of virgin prairie or woodland.

A few years before the second World War it was not an uncommon sight in spring to see near the post office on Portage Ave. palls and baskets full of the showy pink lady's-slipper flowers offered for. sale. As the leaves were always plucked with the flowers, the rootstocks of these plants were doomed to die. The Manitoba Natural History. Society protested to the provincial government officials against this wholesale destruction of a non-toocommon beautiful flower. Unfortunately, it was not expedient for the government to do anything to plotect this flower.

Many States in the U.S.A. and some provinces in Canada have laws which protect many of their native flowers. Here, in British Columbia, it is illegal to pick the blossoms of the flowering dogwoods and the socalled Easter lilies without the permission of the owner of the land on which they grow.

The people should learn that some perennial ilowers can be gathered if enough leaves are left to nourish the roots. for the next season: This is easy to do in the case of the prairie anemone (prairie Crocus) where the flowers appear before the leaves. Plants with only a few leaves, as in many orchids, usually do not survive as the leaves are nearly always taken with the flowers. When flowers of the annuals are gathered, enough of the earliest blooms should be left in order to ensure a good supply of seeds for the next year. If all the flowers are taken that (Continued on Inside Back Cover) 